\title{
におい識別装置「FF-2020」を用いた医薬品の測定例
}

\author{
喜多純一
}

\section{The Introduction of Medical Product's Applications by Using Flavor and Fragrance Analyzer "FF-2020"}

\author{
Junichi Kita \\ Analytical \& Measuring Instruments Division, Shimadzu Corporation; 1 Kuwabara-cho, \\ Nishinokyo, Nakagyo-ku, Kyoto 604-8442, Japan.
}

(Received August 31, 2013)

\begin{abstract}
The design concept of flavor and fragrance analyzer "FF-2020" was descried; at first how to recognize the quantification of odor, introducing traditional quantification of odor and how to compose the analyzer. At last two analysis of the medical goods were described. The most important thing to quantify the odor is to recognize the three faced of odor that is chemical component face, subjective feeling and objective feeling. For the electronic nose like a flavor and fragrance analyzer, objective feeling should be quantified by the analyzer. Then the original mode of analysis was made to realize the quantification of the objective feeling.
\end{abstract}

Key words — three faces of odor; electronic nose; metal oxide semiconductor

\section{1.はじめに}

嗅覚能力については，日常生活において常に使つ ているので，その能力のすばらしさが実感されにく いが，ある側面では，ヒトの嗅覚能力は高価な機器 分析を利用してもいまだ完全には置き換えることが できないほどすばらしい。

例えば感度では，検出限界として bbp レベル以 下まで検知できるにおい種が存在する。これは，通 常においガスの分析に用いられる GC/MS（質量分 析付きガスクロマトグラフィー）において，前段に なんらかの濃縮装置を用いてようやく検出できるレ ベルである，濃縮装置を含めて GC/MS 装置のお よその価格は，約 2000 万円にもなる.

においを有する化学物質の数は，一説には 40 万 種も存在するといわれるが，ヒトの鼻は感度は高い がその化学組成までは特定できない。それは，ヒト のにおい検知メカニズムが，ガスクロマトグラフ ィーのようにカラムを用いて単一成分に分離してか

The author declares no conflict of interest.

島津製作所分析計測事業部（干604-8442 京都市中京区 西ノ京桑原町 1)

e-mail: j-kita@shimadzu.co.jp

本総説は, 日本薬学会第 133 年会シンポジウム S30302 で発表した内容を中心に記述したものである.
ら検知するというものではなく，複合成分のまま複 数の嗅覚レセプター（センサ）を用いてパターン分 析する手法のためである.1

ちなみに，ヒトの場合，機能している嗅覚レセプ ターの数は約 390 種と言われており，におい成分組 成の違いについて，においの質 (品質ではなく種類) として認識をしている．また嗅覚は高感度ではある が，濃度の濃いにおいも感知できるために，他の五 感と同様に，対象物の量（においについてはにおい 物質の濃度）に対して対数で応答するいわゆるウ エーバーヘフナーの法則が成り立っている.

以上のメカニズムによりヒトはにおいを検知して いるので，成分分析で求めたにおい物質 (成分組成) とその濃度に対し，嗅覚で認識しているにおいの強 さと質について直接的には対応がつけづらい．また においを有する成分種が 40 万種もあり，それらの 混合したにおいも考えるとその組み合わせは無数と いってもよいほどの数になり，それらすべてに対 し，色にたとえたとして，赤色や黄色として定義す ることはできないため，においの認識には主観が入 り易いことになる。これがにおいの定量化を難しく している理由となる。このことをまとめたのが Fig. 1 である。 


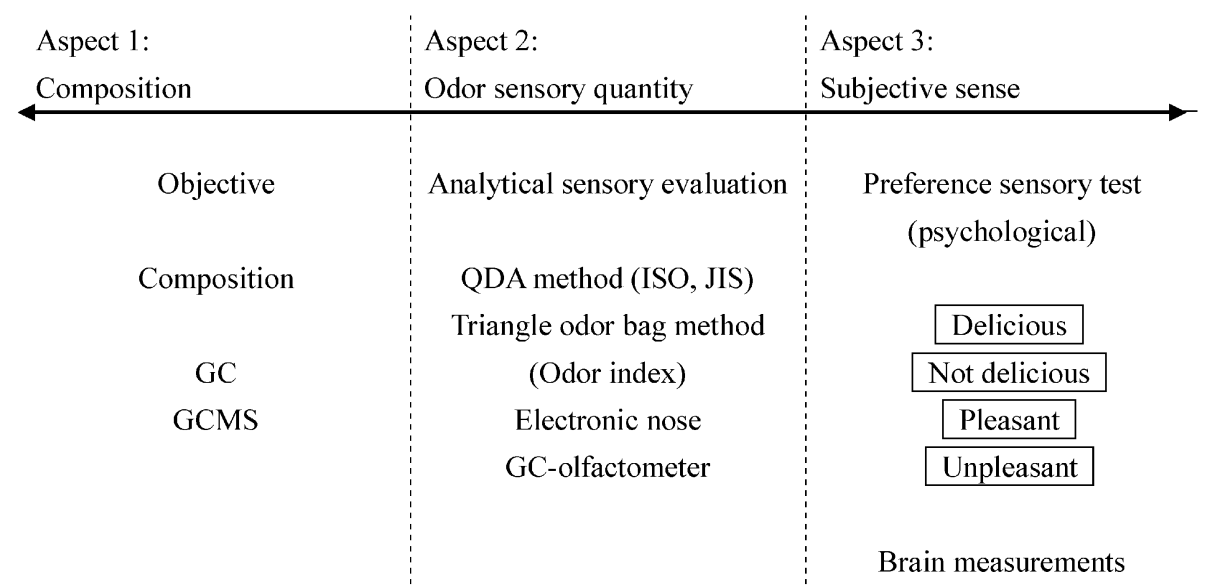

Fig. 1. Three Faces of Odor

Three faces of odor are explained such as face of chemical component, face of objective feeling and face of subjective feeling.

通常，ヒトはにおいを Fig. 1 の一番右の主観的 感覚で認識をしているが，このフェーズではにおい の認知に主観が多分に含まれるため，主観的感覚で 感じた不快なにおいの原因追求には，できるだけ客 観性の高い分析が求められ，左側の成分分析が行わ れる. しかし，成分分析の結果から主観的感覚の結 果を説明することは一般的に難しいことが多い。そ の理由は大きく分けて, 今まで説明したことのまと めになるが，2つの理由がある.

1 つは，においは濃度の対数でにおいの強さが変 わるということと, におい成分の検知閾值（嗅覚で 感じる最低の濃度）が成分毎に大きく異なるため, 成分とその濃度からにおい質と強度への変換が難し い.ただこの部分は慎重に手順を追って進めれば Fig. 1 の中央の嗅覚感覚量（においの強さと質）ま では成分と濃度から客観的に得られる。しかし，こ の中央の嗅覚感覚量から主観的感覚の間では主観が 大きく介在し，成分分析をうまく反映できない場合 が多い.

もう 1 つの理由は，においを構成する成分に分離 してしまうと, 複合臭で存在したときの性質, 例え ば立体障害的なメカニズムと思われるが，いわゆる マスキングやペアリングと呼ばれる現象が見えなく なってしまうためである。そこでわれわれは，にお いの客観評価として GC/MS のような成分分析と は別に，においを成分全体の性質としてとらえ，に おいの強さや質が求められるにおい嗅ぎ GC 若しく は今回紹介するにおい識別装置の有効活用もにおい の定量化方法として提唱している.

\section{2.においの強さ及びにおいの質に対する従来の 定量化方法}

におい識別装置の考え方を説明する前に，従来の においの強さとにおいの質の定量化がごのように行 われてきたかを理解しておく必要がある.

Figure 2 は，悪臭防止法におけるにおいの強さ評 価法の変遷である. ${ }^{2)}$ 日本において，悪臭防止法は 一番系統だつたにおいの強さの評価方法を提供して いる。この悪臭防止法は昭和 46 年に制定された が, その当時, 成分濃度分析を機器分析で行い, そ の濃度からにおいの強さを求める物質濃度規制を導 入すべきか, 嗅覚を利用して, 測定対象のにおいを 無臭空気で希䣋し，無臭になるまでの希釈倍率でに おいの強さを定義する臭気指数規制を導入すべきか 議論になつたと聞いているが，物質濃度規制の方が より客観的ということで採用されたとのことである.

当時は悪臭が発生する場所や，そこで問題になつ ている悪臭成分が特定し易かったという背景もあ

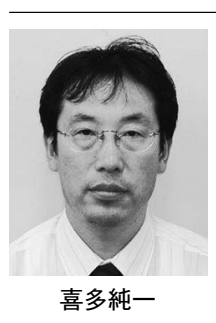

京都大学工学部化学工学科卒業. 1981 年侏島津製作所中央研究所研究員.太 陽エネルギー蓄積高歪み化合物, 赤外 検出器用焦電材料の開発. 2011 年分析 事業部 GCTABU. 高温超伝導体磁気検 出素子の開発, 赤外線液晶チョッパの 開発, 輻射アレーセンサの研究, 導電 性高分子においセンサの研究, におい 識別装置の開発, 以後におい関連の研 究. 2001 年におい識別装置 FF-1 にて 第 4 回日食優秀食品機械資材賞，2007 年におい識別装置 FF-2A にて社におい かおり環境協会平成 18 年度技術賞, 2011 年電気学会進歩賞を受賞. 


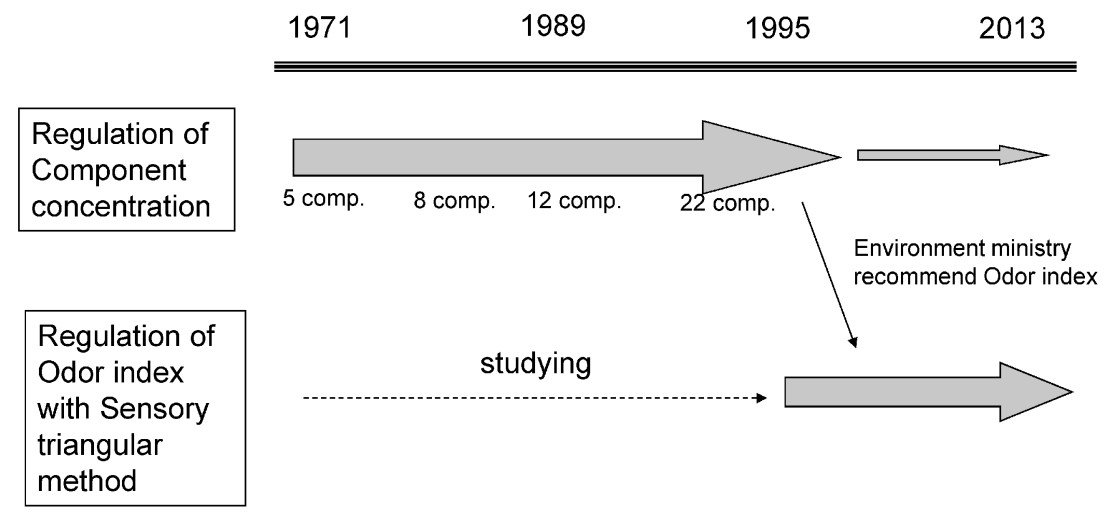

Fig. 2. The Transition of Offensive Odor Control Law in Japan

At first reducing the concentration of malodor's component was used and secondary measuring odor index by human nose was added.

る．例えばし尿処理場，化製工場，塗装工場などが 対象であり，そこで問題となった硫化水素やアンモ ニアなどの 5 物質からの規制で開始され，最終的に は 22 成分まで増やされた。

機器分析で物質濃度が測定できたとしても，物質 毎にその濃度とにおいの強さの関係は異なるため, その関係をあらかじめ求めておく必要がある。 その 関係式をグラフ化したものが Fig. 3 になる。 この 関数は, ${ }^{2)}$ 当時の環境関連の研究所においてクロス チェックをされたと聞いているが，この関数を求め る作業はかなり時間が必要であったことは容易に想 像できる.

Figure 3 からも，におい物質により，臭気強度が 1 になるところ（検知闇值濃度）が物質により大き く異なり, また, においの強さが濃度の対数で変化 することも理解される.

Figure 2 にあるように, 平成 7 年頃になると制定 当初の悪臭源からのにおいは対策が進み，それらの 悪臭の問題は減少してきたが, 代わって焼肉臭や野 焼きなど，一般生活臭が問題になり，臭気指数規制 が導入されることになった。

この背景には, 従来の悪臭 22 物質では新たなに おいには対応できなくなったこと，物質濃度規制を 続けるためには，より多くの対象物質を特定し，そ のたびにそれらのにおい物質の濃度とにおいの強さ の関係を求める必要があり多大な労力が必要なこ と, 成分数が多い複合臭については, いくつかの単 成分の濃度だけでは評価しきれないことなどの背景 があったものと思われる.

臭気指数規制における臭気指数の求め方が Fig. 4

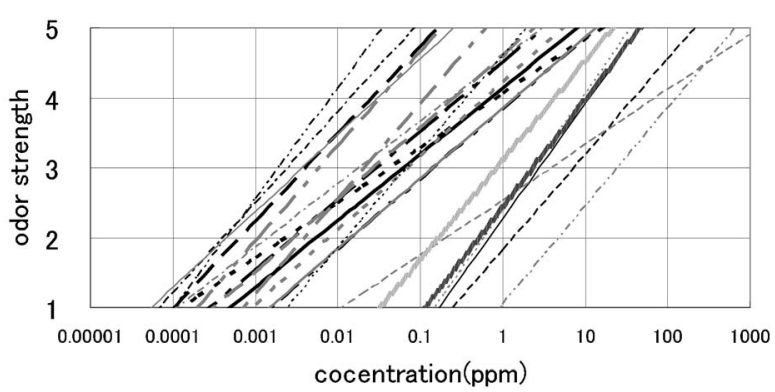

\begin{tabular}{|c|c|c|}
\hline -hydrogen sulfide & - - methy mercaptan & - - dimethyl sulfide \\
\hline - - dimethyl disulfide & - - acetaldehyde & _ propion aldehyde \\
\hline - "n-butylaldehyde & - - 'isobutylaldehyde & - -n-valeraldehyde \\
\hline - isovaleraldehyde & - methyl isobutyl ketone & ---- etyl acetate \\
\hline …...poropionic acid & $\cdots \cdots$-butyric acid & -...v valeric acid \\
\hline -isovaleric acid & ----isobutanol & …... ammonia \\
\hline trimethylamine & -.... toluene & styrene \\
\hline
\end{tabular}

Fig. 3. The Relationship Function between Odor Concentration and Odor Strength

に示されている．この方法は三点比較式臭袋法を呼 ばれ，図中の写真にあるように，6名のパネルを用 いて測定を行う。それぞれのパネルは，嗅覚試験に より 5 種が嗅ぎ分けられる必要があり, 試験全体の オーガナイズは, 臭気判定士が行うことが望まし い. 試験の手順としては，まず，臭気判定士が先に サンプル臭を 3 倍系列 $(30,100,300,1000$ 倍…な ど）に希釈し，どの当たりで無臭になるか見当をつ けておき，その 30 倍若しくは 100 倍濃いところか ら試験を開始する.

試験は，6 名に 3 つのバッグを提示し，3つのバ ッグのうち 1 つには，サンプル臭が何倍か希釈され たものが入っており，残りの 2 つには無臭空気が入 つている. 6 名のパネルはその 3 つのバッグのに おいを嗅ぎ，どれが無臭でないかを嗅ぎ分ける. 


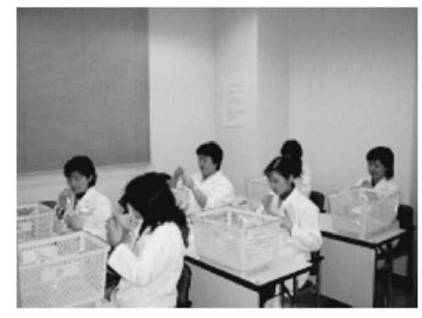

Three bags are served to 6 panels. One of them include diluted odor sample and the others have clean air. Each panel must judge which bag has odor.

Dilute degree was 10000 then odor concentration was 10000 . Odor index $=10 \times \log$ (odor concentration) then 40 .

If dilute degree was 1000 then odor concentration was 1000. And Odor index was 30.

\begin{tabular}{|c|c|c|c|c|c|c|c|c|c|}
\hline \multicolumn{2}{|c|}{ Dilution factor } & $\times 30$ & $\times 100$ & $\times 300$ & $\times 1000$ & $\times 3000$ & \multirow{2}{*}{$\begin{array}{l}\text { Odor } \\
\text { threshold of } \\
\text { each panel } \\
\qquad \mathrm{Xi}\end{array}$} & \multirow{2}{*}{$\begin{array}{l}\text { Top and } \\
\text { bottom cut }\end{array}$} & \multirow{2}{*}{$\begin{array}{l}\text { Odor } \\
\text { threshold } \\
\quad \times\end{array}$} \\
\hline \multicolumn{2}{|c|}{ Log of Dilution factor } & 1.48 & 2.00 & 2.48 & 3.00 & 3.48 & & & \\
\hline \multirow{6}{*}{ PANEL } & A & 0 & 0 & 0 & 0 & $x$ & 3.24 & $x$ & \multirow{6}{*}{2.87} \\
\hline & $B$ & 0 & 0 & 0 & 0 & $x$ & 3.24 & & \\
\hline & $\mathrm{C}$ & 0 & 0 & $x$ & & & 2.24 & $x$ & \\
\hline & $\bar{D}$ & 0 & 0 & 0 & $x$ & & 2.74 & & \\
\hline & $\bar{E}$ & 0 & 0 & 0 & 0 & $x$ & 3.24 & & \\
\hline & $\mathrm{F}$ & 0 & 0 & $x$ & & & 2.24 & & \\
\hline
\end{tabular}

Fig. 4. The Measuring Odor Index Method by Human Nose

Figure 4 の下側の表に実際の試験例が示されている が，濃度の高いところ（希䆏率が小さいところ；表 の左側）から試験が行われるが，この試験の場合， 30 倍と 100 倍については A-F の 6 名すべてのパネ ルが嗅ぎ分けることができ， 300 倍では，C と F の パネルが嗅ぎ分けられなかった。嗅ぎ分けられなか つたパネルはそこで試験が中断され，すべてのパネ ルが嗅ぎ分けられなくなるまで試験は進められ，最 後に, 一番感度の高かったパネルと, 感度が低かっ たパネル 2 名を除き，残り 4 名の結果の平均から臭 気指数が決定される.

臭気指数の計算方法は，無臭になるまでの希釈倍 率がそのまま臭気濃度と呼ばれ，臭気指数は臭気濃 度から下記の式により計算される。

臭気指数 $=10 \times \log _{10}$ (臭気濃度 $)$

Figure 4 の表では，臭気閾值が既に記載されてい るが,

臭気閾值 $=\log _{10}($ 臭気濃度 $)$

のため, この試験の臭気指数は, 臭気閾值の 10 倍 なので 29 になる（臭気指数は小数点以下について は四捨五入することになっている).

悪臭防止法については，どんなに快適なにおい種 であっても，嗅ぎたくない人にとっては不快なにお いになってしまうので，におい質を問わない.

次に，におい質を定量的に求める方法としては, ISO 化されている quantitative descriptive analysis (QDA) ${ }^{3)}$ がある.

この QDA 法は，どの食材でも使える官能特性用
語を探すのではなく，食材ごとに，それを表すのに ふさわしいにおい質を選定する方法である，具体的 な手順は，(1)評価するサンプル間のにおいの違いを 表現する言葉だしを行う。この言葉は，どのような におい質のことを言っているのかを明確にするため に，実際に準備ができるにおいを選定することが望 ましい。（2)それらの言葉だしから，表現は違うが同 じにおい質のことを表わしているものを省き，官能 特性表現用語を選定する。（3)選定された官能特性表 現用語を使つて熟練したパネル 12 名程度で試し評 価と尺度あわせを行い，尺度に大きなばらつきがな ければ，(4)本評価を行う.

本評価では，官能特性表現用語の得点を用いた レーダーチャート以外に，統計検定として分散分析 や多重比較，多変量解析として主成分分析やPLS 回帰分析などが行われる。

Figure 5 では，実際に市販の食パンについて QDA 法を適応したレーダーチャートが示されてい る.

\section{3.におい識別装置}

3-1．装置原理＼cjkstart官能評価を利用せず，装置の みでにおいの強さとにおいの質の情報が得られるに おい識別装置を説明する。におい識別装置の設計思 想のポイントを記載したものが Fig. 6 である.

成分分析では，においに含まれる化学成分とその 濃度を求めることになるが，におい識別装置では, 嗅覚と同様のにおい検出機能を持たせ，においの強 さ（臭気指数相当値）とにおいの質（基準のにおい 
からの近さ度合いを\%で示す）というように，嗅覚 に近い出力が得られるようにしている.

嗅覚に近い出力が得られるように，カラム等で分 離をせず複合臭のまま複数の金属酸化物半導体セン サで検出するようにしている．またこの金属酸化物 半導体センサは，ガス警報機などにも使われている

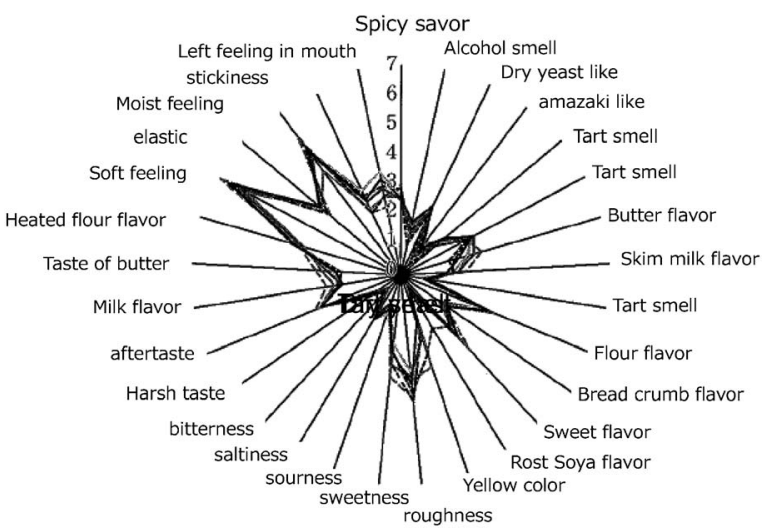

Fig. 5. Output of QDA Analysis of Pain de Mie
が，濃度の対数で応答するため，嗅覚と同様にウ エーバーヘフナーの法則に則る，さらに，嗅覚はに おい物質毎に検出できる濃度が（検知閾值）が大き く異なるが，金属酸化物半導体の感度は，嗅覚レセ プターの感度とは一致しないため，後で説明する解 析処理で嗅覚感度に合わせるようにしている.

装置の全景を Fig. 74) に示す。一番左側の金属容 器がアロライトボンベと呼ばれ，基準のガス 9 種分 用意されている，それらの基準ガスは，センサ感度 の校正に使用するとともに，スタンダードモードと 呼ばれる解析方法の基準ガスになる。その右はバッ グ用のオートサンプラで，写真ではセットされてい ないが，黒いゴムの部分に，サンプルバッグが左右 6 個ずつ合計 12 個が設置できるようになっている.

その右側は， $100 \mathrm{~mL}$ のガスタイトシリンジが自 動で上下する機構を有するガスの希釈混合装置で, 今回は説明を省略するが，センサ出力の濃度に対す る非線形性が，におい質評価の誤差になるのを避け

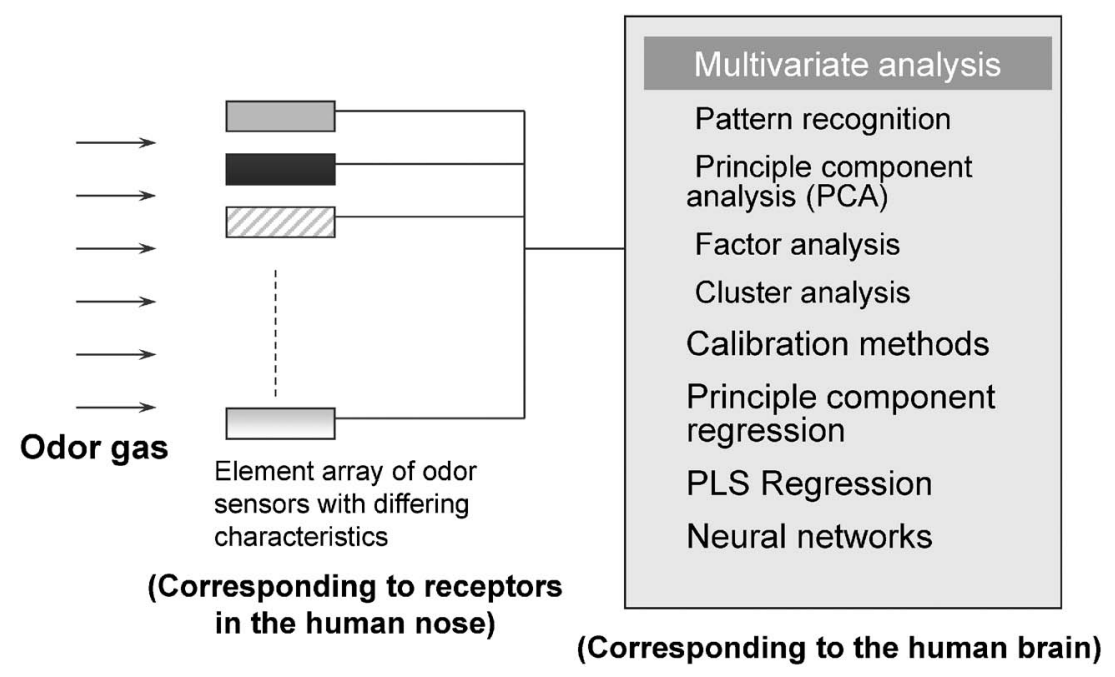

Fig. 6. Original Concept of Flavor and Fragrance Analyzer

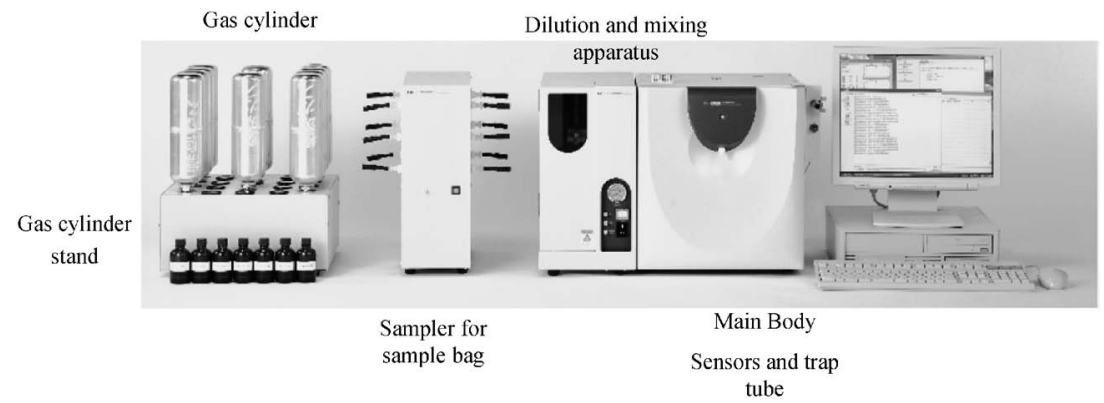

Fig. 7. Flavor and Fragrance Analyzer FF-2020S System 


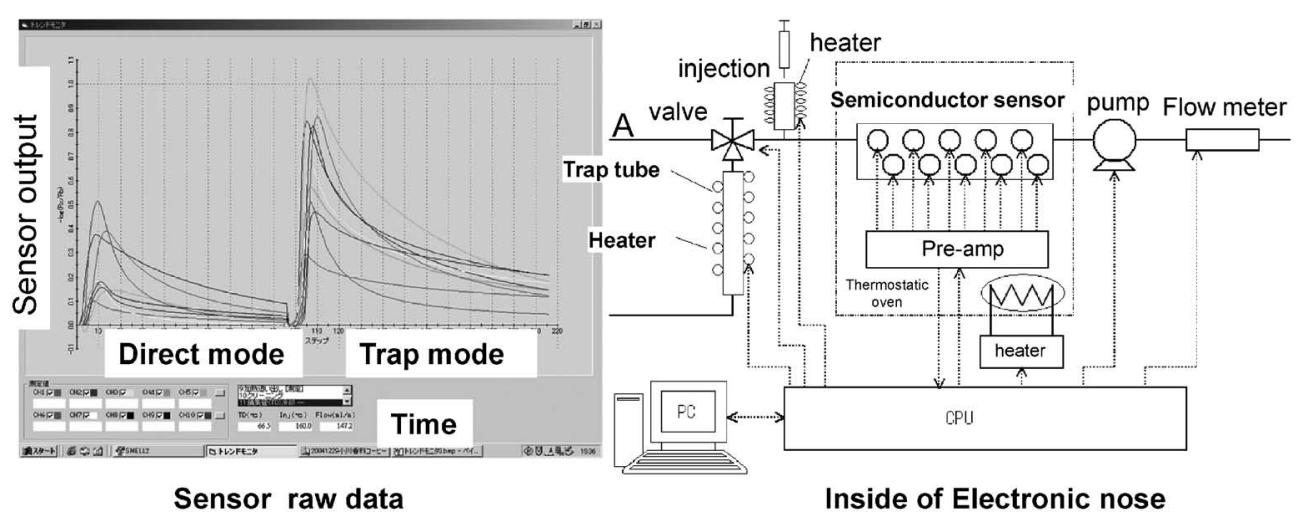

Fig. 8. The Mechanism of Flavor and Fragrance Analyzer

るために, 10 個のセンサの総合出力を一定に保つ ために使うのが主目的である.

その右が本体で, ここにセンサ 10 個とサンプル ガスを濃縮する捕集管が入っている.

実際の構成と動作を示したのが，Fig. 85) であ る. 図の右半分に，本体の構成が記載されている. バッグサンプルの場合には，Aの場所から導入さ れたにおいサンプルガスが，いったん捕集管に通さ れ濃縮される。濃縮後, 捕集管の反対側から乾燥窒 素を流し, 捕集管から不要な水蒸気を追い出すとと もに，捕集管にトラップされ難いにおいガスを 6 秒 だけセンサに導き, ダイレクトモードの信号とす る. その後, 十分に捕集管を乾燥窒素で乾燥後, 捕 集管温度を $40^{\circ} \mathrm{C}$ から $220^{\circ} \mathrm{C}$ まで加熱することによ り, 出てきたにおいガスをセンサに導き, 捕集管 モードの信号を得ている.

以上の工程により，捕集管モードの信号は，水蒸 気の影響がない，またサンプルが濃縮されているの で高感度化された信号が得られ，ダイレクトモード は，捕集管にトラップされ難い成分の信号が得られ る.

3-2. 信号解析 3-1. の測定を行うと, Fig. 8 の左側の信号が得られるが，ダイレクトモード及び 捕集管モードの 10 個のセンサ信号のピーク值を用 いて以後の解析を行う.ダイレクトモードも捕集管 モードも信号は異なるものの解析方法は同じである ため, 捕集管モードの信号解析方法について説明す る.

Figure 9 はそのピークデータからの解析方法だが, ch1 から ch10 の出力軸が記載されているが, これ らは同一平面上に描かれているように見えるが，実

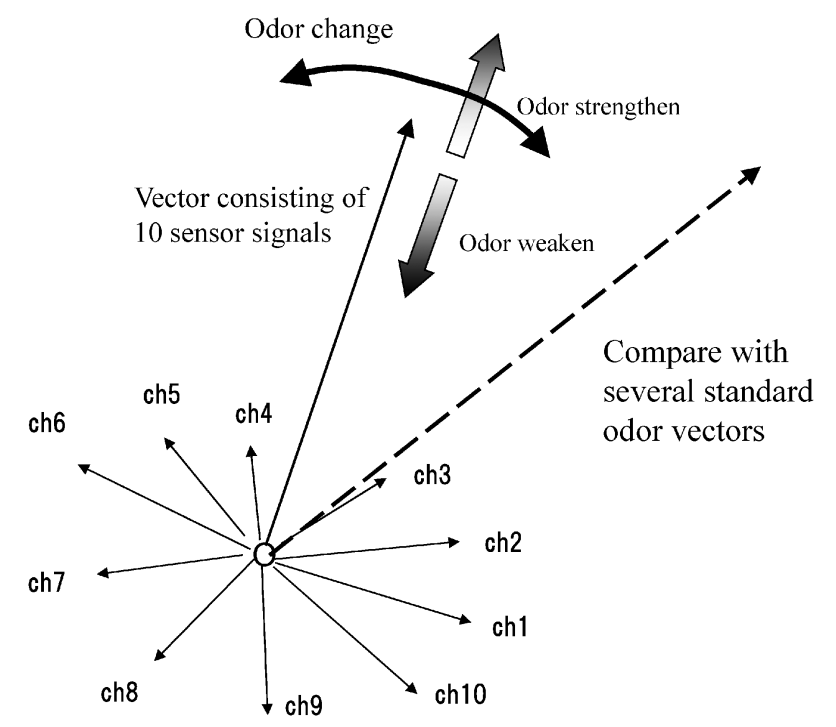

Fig. 9. Principle of the Signal Processing of Flavor and Fragrance Analyzer

際は 10 次元空間を作る軸となる. 各軸について各 センサのピーク出力を目盛ると, それらの出力を基 に 1 つのセンサ出力ベクトルが設定できる.

このベクトルに対して, より強いにおいを測定す るとベクトル長が長くなり，におい質が違うとべク トルの方向が変わる。これによりにおい強度, にお い質の変化分は求めることができるが, これだけで は相対比較となってしまう。それを避けるために, あらかじめ基準となるにおいを複数種設けて，それ らのにおいべクトル（Fig. 9 では点線で引かれたべ クトル）を基に未知のにおいの強さと質を判定する のがにおい識別装置の解析原理である.

その原理を基に, Table 1 の 6 つの解析方法が準 備されているが, ここでは, 医薬関係品のにおいを 
Table 1. The Sorts of Signal Processing Methods of Flavor and Fragrance Analyzer

\begin{tabular}{|c|c|c|c|c|}
\hline & Target item & Analysis method & Principle & Scale \\
\hline 1 & $\begin{array}{c}\text { odor Inensity } \\
\text { odor similality } \\
\text { (similaity to } 9 \text { std gas) }\end{array}$ & standard mode & $\begin{array}{l}\text { all odor is assigned to be } \\
\text { divided into } 9 \text { gases }\end{array}$ & odor index \\
\hline 2 & odor Intensty & $\begin{array}{l}\text { user mode with intensity } \\
\text { parameter }\end{array}$ & caliblated with target gas & odor index \\
\hline 3 & $\begin{array}{l}\text { odor similality with one } \\
\text { reference gas }\end{array}$ & user mode & $\begin{array}{l}\text { degree of angle between } \\
\text { odor vector }\end{array}$ & $\begin{array}{c}\% \\
\text { choose from } 3 \text { full scale }\end{array}$ \\
\hline 4 & $\begin{array}{l}\text { odor similality with two } \\
\text { reference gases }\end{array}$ & $\begin{array}{l}\text { user mode with } \\
\text { two reference gases }\end{array}$ & $\begin{array}{c}\text { make } 100 \% \text { between two } \\
\text { reference gases }\end{array}$ & $\%$ \\
\hline 5 & deviation from reference gas & odor deviation map & $\begin{array}{l}\text { caliblate with deviation gas } \\
\text { from reference gas }\end{array}$ & $\begin{array}{l}\text { angle or discrimination } \\
\text { threshold }\end{array}$ \\
\hline 6 & visualization of separation & $\begin{array}{l}\text { principal component analysis } \\
\text { or cluster analysis }\end{array}$ & reduction of dimensions & $\begin{array}{c}\text { dimensionless and relative } \\
\text { value }\end{array}$ \\
\hline
\end{tabular}

測定した 1 番目の解析方法と 3 番目の解析方法の応 用例を紹介する。

\section{4. 医薬関係品の測定}

\section{4-1. スタンダードモードの応用例 Table 1}

の 1 番目は，センサの校正に用いた 9 種の基準ガス を基に解析する方法である。具体的には Fig. 10 の 左側に示されるが，9 種の基準ガスベクトルを測定 しておき，それを基に未知のにおいの強さを臭気指 数相当值で，また，においの質については 9 種の基 準ガスとの近さ度合いを類似度\%で求める.

未知のにおいガスのベクトルの方向と，基準ガス ベクトルの方向との角度に応じた類似度（\%）を求 めて，類似度レーダーチャートを表示する。 また， その 9 種の類似度のデー夕を基に，未知のにおいが この 9 種の基準ガスの混合でできていると仮定し, その混合割合を臭気指数の尺度で表したものが臭気 寄与である.さらにその 9 種の臭気寄与を総合して 全体の臭気指数相当值を求めている.

Figure 10 では素材の異なるゴム手袋について調 べており， $\mathrm{A}$ に比べて $\mathrm{B}, \mathrm{C}$ とにおいが弱いのがわ かる。また素材 $\mathrm{A}$ について $\mathrm{A}$ 社のものだけ少しに おい質が違うことが分かる.

この解析方法を用いて，アルミピローの内部のに おいを求めたのが Fig. 11 である.ここでは A 社, $\mathrm{B}$ 社， $\mathrm{C}$ 社を比較しているが， $\mathrm{C}$ 社が特ににおいが 強いことが分かる。 またにおい質においても $\mathrm{C}$ 社 だけがアルデヒド臭系や有機酸臭系のにおい質に近
いということも分かる.

これらの結果が， 1 サンプル当たり 40 分程度で 得られる。

4-2. ユーザーモードの応用例 次にユーザー モードという解析方法を貼り薬に対する香料のマス キング効果判定に利用した場合の結果を紹介する.

ユーザーモードとは Fig. 12 に示すように，1 若しくは 2 つのユーザーが定めた基準臭との近さ度 合いでサンプルのにおい質を類似度\%で表わすもの である。

Figure 12 の左側が，基準のにおいが 1 つの場合 であり，その類似度についてはフルスケールを 3 段 階に設定できる。同一食材間のにおいなどほとんど 同じにおいの微妙なにおい質の差を見る場合は,

Fine モードを利用し, Fine モードのフルスケール は $3.5^{\circ}$ である.プラスティックの種類の違いなどを 見る場合であれば Medium を利用し，そのフルス ケールは 7 である。 Coarse モードの類似度は， ス タンダードモードの類似度に近く, 全におい空間を 表現する時に用い，フルスケールが 140 である.

今回このユーザーモードの 2 つの基準臭を用いる 方法を使って，貼り薬の酢酸臭をマスキングする香 料を探した結果を紹介する。まず準備したサンプル としては，Fig. 13 に示すように，それぞれの香料 $\mathrm{X}$ に対して，3つのバッグを準備する．1つは酶酸 のみが入っているバッグで，もう 1 つ香料 Xしか 入っていないバッグ，それに酢酸と香料 Xが混在 


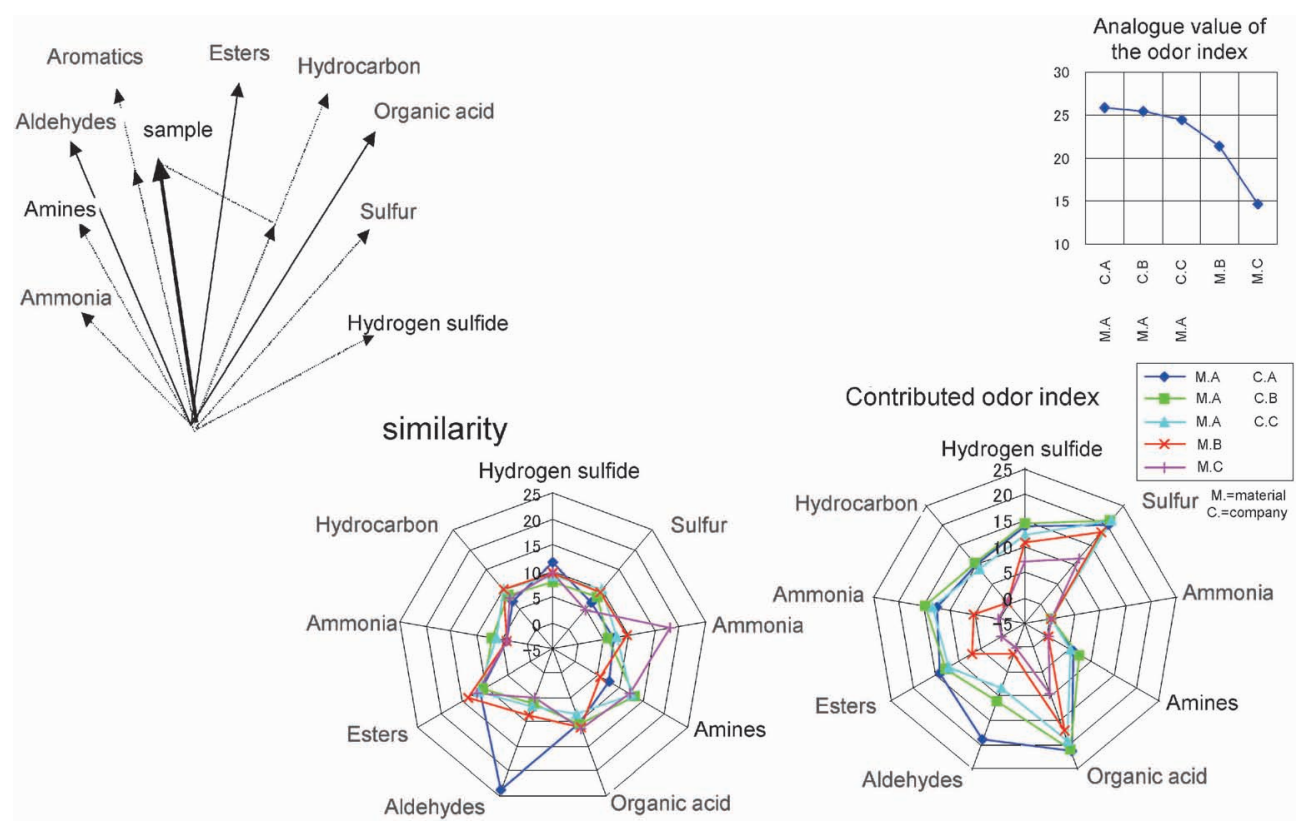

Fig. 10. The Result of Standard Mode Analysis of Latex Gloves

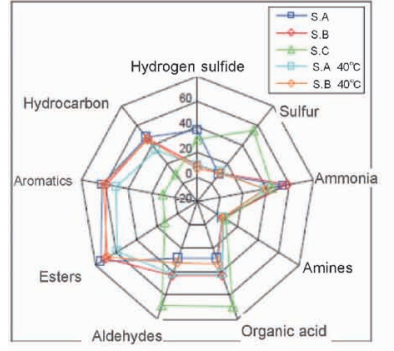

similarity

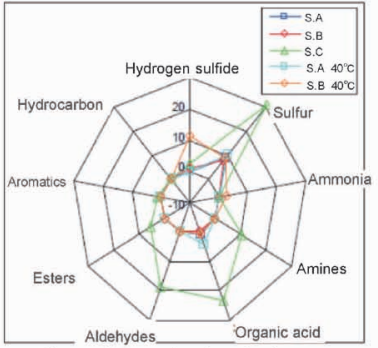

Contributed odor index

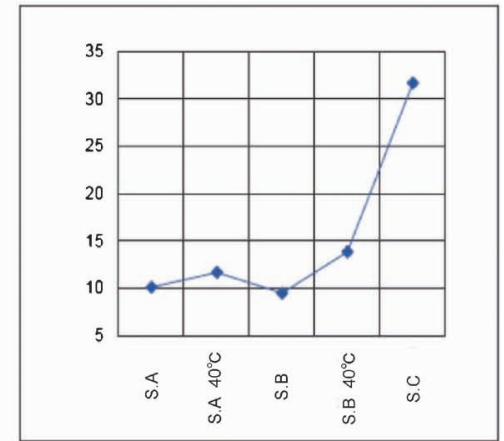

Analogue value of the odor index

Fig. 11. The Result of Standard Mode Analysis of Aluminum Pillow

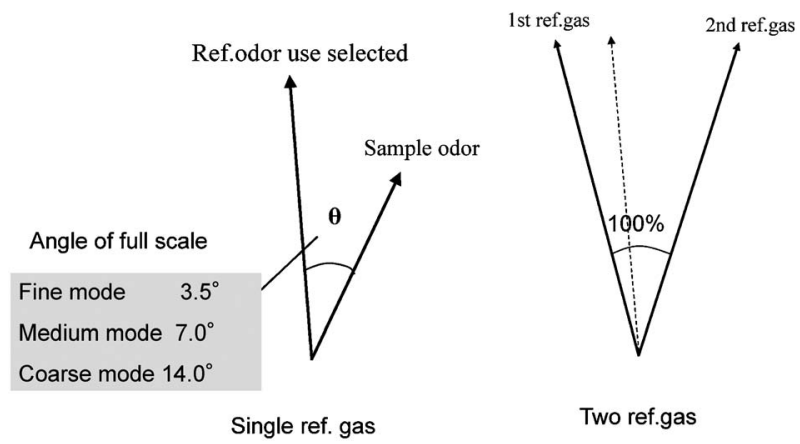

Fig. 12. The Principle of the User Mode Analysis
したバッグである。香料 X の種類は，香料 $\mathrm{G}$ ，香 料 $\mathrm{M}$ それに香料 $\mathrm{P}$ の 3 通りであつた.

これらをにおい識別装置で測定し，酢酸のみと， 香料 Xのみを 2 つの基準臭として, 酢酸に香料 $\mathrm{X}$ を混入したものが両者から見てどこに位置づけされ るかを測定した。

Figure 13 に結果を示すが，M が一番酢酸から遠 いという結果になり，マスキング効果があることが 分かり, 官能とも一致した。

これ以外に Table 1 の 2 番目の方法は, においの 強さを求めたい場合に，9種の基準ガスを基準ガス 
Similarity with acetic acid

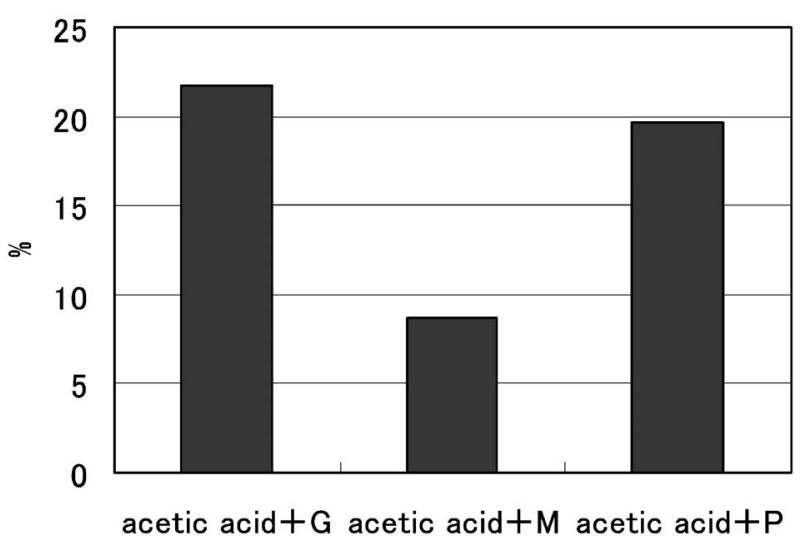

Fig. 13. The Result of User Mode Analysis of Adhesive Skin Patch

に用いるのではなく，求めたいにおいにおいてその 検知闇值を求めておいて，そのにおいでにおい識別 装置を校正する方法である。この求めたいにおいは 単成分でなくても複合臭でもよい。この方法は現 在，繊維業界において ISO 化が進められており， 2014 年の夏には ISO になる予定である.

\section{5. まとめ}

においを定量化するにあたり，3つの側面を正確 に把握しておく必要があることを記載した。官能評 価には，主観をできるだけ排した分析型官能評価と 主観が含まれた嗜好型官能評価があり, 分析型官能 評価については，におい成分からその応答を予測す ることができるが，嗜好型官能評価については主観 が入ってくるので, におい成分だけからはその応答 を予測することはできないことを説明した. よって この両者を分けずに論じることはかなり危険であ り, 分析型官能評価といっても嗅覚が濃度の対数で においの強さを感じること, 成分毎にその検知閾值 が大きく異なること，またこの検知閾值が物質の化
学構造から現状では検知閾值は予想できないことに 注意が必要である.

さらに，いくつかのにおい物質が混合されること により，マスキングやペアリングと呼ばれる現象が 起こることにも注意が必要である。このような条件 の中で，におい識別装置は，嗅覚に似た検知機構を 利用して嗅覚に近い感度が出せるようになってきて おり，その装置の仕組みと信号解析の原理を説明し た.

また，これらの解析方法を利用した場合の医薬品 関連の測定事例を紹介した。

今後さらに，検討が加えられ，まず分析型官能評 価自身の求め方を確実なものにし，その信頼できる 值に近づける努力が少しずつ続けられるものと思わ れる。

安全で快適な暮らしにはにおいという側面は無視 できない. 物質構造から検知闇值が求まることや, マスキングのメカニズム解明など, 基礎となる科学 が発展することも期待したい.

\section{REFERENCES}

1) Buck L., Axel R., Cell, 65, 175-187 (1991).

2) “Akushu-Boushi-Ho Handbook," 4th ed., ed. by Akushu-Hourei-Kenkyukai, GYOSEI Corporation, Tokyo, 2001.

3) Stone H., Sidel J., Oliver S., Woodlsey A., Singleton R. C., Food Technol., 28, 24-34 (1974).

4) FF-2020 system: 〈http://www.an.shimadzu. co.jp/prt/ff/ff2020.htm $\rangle$, Shimadzu Corporation Web, cited 25 August, 2013.

5) Kita J., Okada M., Akamaru H., Kinoshita M., J. Japan Association of Odor Environment, 37, 172-178 (2006). 